\title{
Qualitative technical design is fundamental for a successfully implemented project
}

\author{
Martynas Gedaminskas \\ Vilnius Gediminas Technical University, Sauletekio al. 11, LT-10223 Vilnius, Lithuania
}

\begin{abstract}
Technical design of a structure is the first stage of a project, and its solutions are further detailed in the working design. Technical design is to be developed as a single document, predefining basic, functional (operational), architectural (aesthetic), technological, technical, economical, quality requirements as well as other parameters and characteristics of a structure. Technical design is to be developed in compliance with the requirements of the Law on Construction and Technical Construction Regulation No. STR 1.05.06:2010, Structure Design, of the Republic of Lithuania.

It is not only the technical design regulations that have an impact on the development of a qualitative design; the development of the terms of reference, clearly specifying the items to be executed or implemented and their scope, detailing and analyzing the needs, expectations and financial capacities of and employer are equally important for the development of technical design. Furthermore, the design developers (i.e., human resources) make a huge, if not basic, impact on the quality of technical design. However, the lowest price principle is being applied when making award decisions in the recent public tenders for design services. As we know, the cheapest not always means the best. Therefore the criteria of the economic advantage, embracing not only the criteria of price and time for the development technical design, but also such new criteria as, e.g., the experience of human resources and the company itself (ability to complete contract on time), etc., could be advantageous for the award decisions in the tenders for the selection of technical design developer (designer).

The prices of construction works offered by tenderers are quite often much higher compared with the cost estimates, developed by using Sistela software, contained in technical designs in the tenders for the railway construction works. Why? The use of Sistela software and the average market prices (the status of which is only of recommendable character), offered by it, for actual works and materials is problematic for the railway reconstruction or construction works, as Sistela software does not contain unit prices applicable for specific works and machines. In addition, a particular attention is to be given to the selection of the technologies of works and their comprehensive description in technical designs.

Only qualitative technical design may ensure smooth project budget flows, reaching of milestones, proper works arrangement and performance of construction works.

For the improvement of the quality of the technical designs the procedure for the development of the terms of reference as well as the contents of the technical design itself are to be upgraded, unit prices for the specific railway works included into Sistela software, and the new criteria for the designer award decisions created.
\end{abstract}

Keywords: design; terms of reference; quality; price; railway.

\section{Documents regulating design}

The system of documents regulating design is comprised of legal, technical and other norms, regulating design process (Fig. 1).

The basis of documents regulating design in the Republic of Lithuania is the pool of documents approved or adopted, following established procedure(s), by relevant public institutions, authorized by the Government, by entities, organizations, enterprises and companies. The technical norms regulating design include technical construction regulations, standards, design rules, technical certificates, methodical instructions and recommendations, the most essential of these being the technical construction regulations, approved by the Minister of Environment [1].

Corresponding author: Martynas Gedaminskas. E-mail address: m.gedaminskas@gmail.com

http://dx.doi.org/10.3846/enviro.2014.151

(C) 2014 The Authors. Published by VGTU Press. This is an open-access article distributed under the terms of the Creative Commons Attribution License, which permits unrestricted use, distribution, and reproduction in any medium, provided the original author and source are credited. 


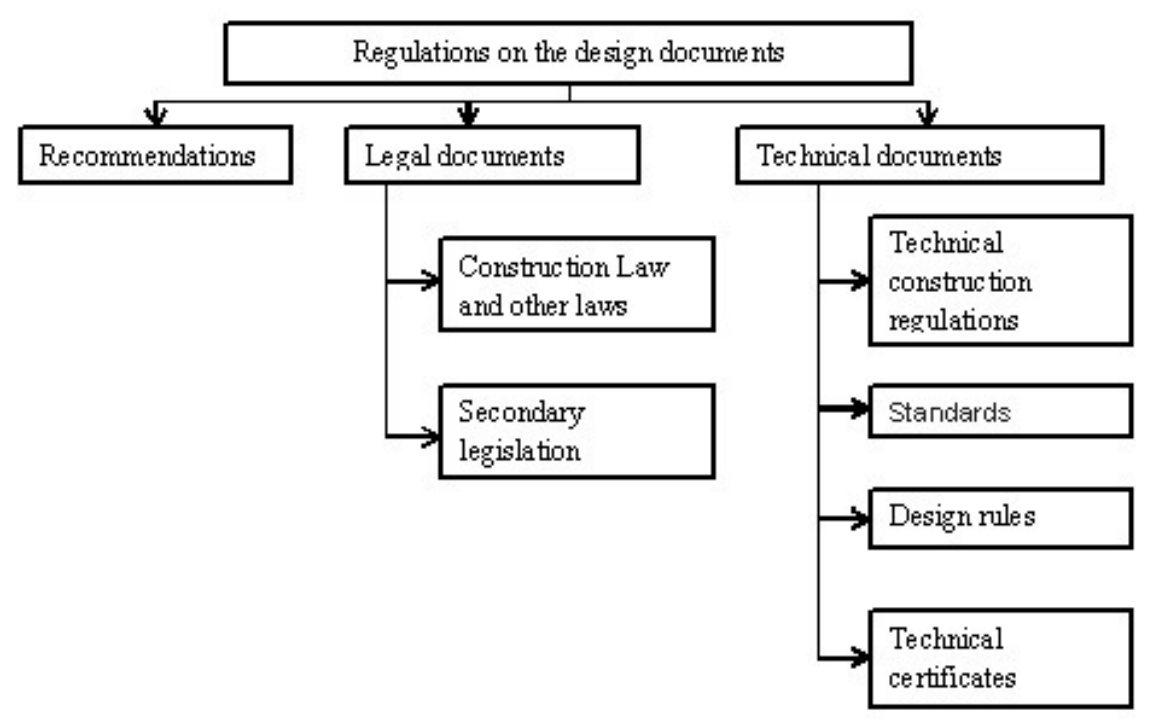

Fig. 1. System of documents regulating design

The Law on Construction, secondary legislation and technical construction regulations are mandatory for all participants of construction/design processes. All other construction norms are to be complied with on voluntary basis except the cases when technical construction regulations or other mandatory legislation requires the mandatory compliance with certain standards, rules, technical certificates, methodical instructions or recommendations.

The provisions regulating the composition of national system of technical construction documents may not contradict the principles and requirements for systems of technical construction norms of the European Union and of international organizations joined by the Republic of Lithuania. Certain technical construction norms of international and European organizations, technical construction norms of foreign counties (national norms) and those adopted by foreign organizations may be also applicable in Lithuania; such technical construction norms are applicable as technical construction norms the Republic of Lithuania.

The main objectives of construction/design norms are to:

- Ensure safe and healthy living, work and leisure conditions for all population;

- Ensure safe and healthy living, work and leisure conditions for disabled;

- Enforce rights of citizens, society and the state, granted by the laws;

- Ensure the integrity between construction/design and environment as well as cost-effective consumption of land, water, forestry, etc., resources;

- Preserve cultural heritage.

Law on Construction of the Republic of Lithuania was adopted by the Seimas the Republic of Lithuania on 19 March 1996, and amended by an issue of a new edition, on 8 November 2011 [2]. The Law on Construction is a core law regulating construction process in Lithuania. It sets up the basic requirements for built, reconstructed and repaired structures in the Republic of Lithuania, the procedure of the survey, design, construction, reconstruction and repair, etc. of such buildings, the relations between legal and natural persons participating in the construction process as well as the principles of the respective activities of governmental institutions. The provisions contained in the Law on Construction generally prevail over the provisions of other legal acts. However, in the event of the contradictions between the provisions contained in the Civil Code, Law on Public Procurement and Law on Construction, the provisions of the Civil Code the Law on Public Procurement, being of generic nature, are to be applied rather than the provisions of the Law on Construction, which are of special nature [3].

Technical Construction Regulations are legal acts setting up the technical requirements for structures, their construction, design and use as well as for construction supervision, or refer respective standards or rules for construction, structure use and construction supervision. The main objective of the regulations is to establish investment planning, structure design and construction procedures harmonizing them to the greatest possible extent with the ones recommended by international institutions and, particularly, FIDIC (International Federation of Consulting Engineers).

Rules for construction, structure use and construction supervision -are the documents registered following procedures established in the Republic of Lithuania, which specify the ways and methods to reinforce the technical construction regulations.

Standard is a document developed with the concord of certain parties and approved by a notified body, setting up rules, general principles and characteristics suitable for generic use, and which is aimed at the regulation of a certain area. Standards may be national, transposed European or international ones, if they do not contradict the laws of the Republic of Lithuania. 
Technical certificates are the documents developed and approved following certain procedures, certifying the suitability of products for the use in construction.

Methodical instructions and recommendations are the documents, published by design and construction companies, science and education institutions, describing ways and methods to enforce construction regulations.

\section{Terms of reference for structure design and technical structure design}

Terms of reference for structure design consists of the scope of design services, actual terms of reference for design and employer's requirements. It is the document approved by the employer describing the scope of design, and the outlay of the main functional, architectural, technical, qualitative, economical and other indicators to be achieved and the requirements to be complied with during the design. The terms of reference are to become an integral part of design contract. The contents of the terms of reference depends on the purpose of the structure designed and the ideas of the employer, however, generally it includes the following data [4]:

- title of structure (group of structures);

- Project development stage (technical design, working design, technical working design, simplified design);

- Source of funds (public, municipal, EU structural funds, private, etc.)

- Procurement method for construction works and equipment or the contractor selected;

- Project design manager (when parts of design or designs of individual structures are to be developed by different designers);

- Scope of design services: conventional services (mandatory for the designer under the Law on Construction), additional services (services required by the employer from the contractor under the design contract), time schedule (scope of design services and the schedule for their rendering may be submitted as a separate annex to the design contract).

- List of mandatory documents produced by the employer.

Terms of reference may have the following annexes:

a) Employer's requirements, specifying law and norms applicable for the design, functional (purpose) and use (operational) indicators as well as the requirements for the structure (its parts and its engineering systems), technical, architectural, quality and other requirements for design solutions split as per individual parts of the design. This annex also contains the sequence of design and construction processes, instructions for the approvals by the employers and other parties of the process, requirements for the appearance and contents of the design documents, number of copies to be delivered to the employer, etc.

b) Data about equipment or construction products chosen or purchased by the employer, or authorization to the designer to choose them in the design;

c) Staff, equipment, subsistence and nominated subcontractors envisaged by the employer to facilitate the rendering of consultancy/design services;

d) Schedule for the submission to the designer of the mandatory documents for the design by the employer. If the employer authorizes the designer to obtain such documents by the design contract, such annex is not to be developed.

1. Technical structure design is the first and most important stage of design; its solutions detailed in working design. Technical design is to be developed as an unanimous document, setting up basic, functional (purpose), architectural (aesthetic), technological, technical, economical, quality requirements, other indicators and characteristics of the structure designed;

2. The composition, scope and detail of technical design is to be sufficient to understand the idea of the employer, for the experts' review of the design, for the calculation of construction costs, selection of the works contractor, issue of construction permit and the development of working design. In general, technical design is composed of the following parts [5]:

1.1.1. General;

1.1.2. Plot arrangement (plot plan);

1.1.3. Architectural;

1.1.4. Constructional;

1.1.5. Technological;

1.1.6. Access;

1.1.7. Water and sewerage;

1.1.8. Heating, ventilation and air conditioning;

1.1.9. Gasification;

1.1.10. Electro-technical;

1.1.11. Electronic communications (telecommunications);

1.1.12. Burglar alarm systems;

1.1.13. Fire alarm systems;

1.1.14. Processes - control and automation;

1.1.15. Environment protection (if required); 
1.1.16. Nuclear safety (if required);

1.1.17. Preparation for construction and arrangement of construction works;

1.1.18. Estimates of construction costs;

1.1.19. Economical;

1.1.20. Bills of quantities;

1.1.21. Other parts, depending on the specifics of a structure designed.

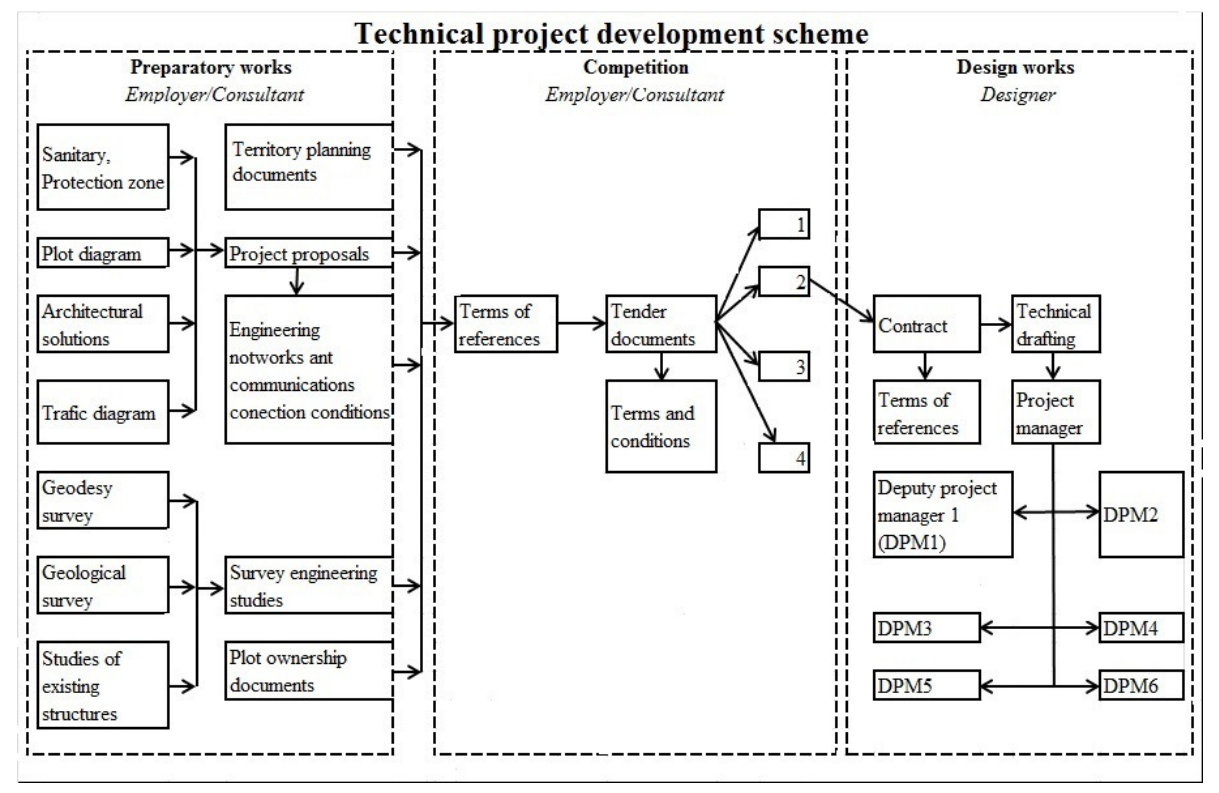

Fig. 2. Sequence of technical design preparation

\section{Potentials for the improvement of technical design quality}

Public procurement. Contracting authorities, when launching public procurement for design and construction work, is almost always choose the lowest cost criterion to the detriment of the quality of projects and often inefficient use of resources for design works. Lately, the discussion regarding the possibility to launch public tenders for the design services based on the economic advantage criteria had intensified, but experience shows that it is just words. In recent years, based on the data of the Public Procurement Office, the number of design services acquired based on the economic advantage criteria is approximately only 1 to 35 purchased by applying the lowest price criterion [6]. By purchasing of design services based on economic advantage criteria one could take into account not only the tender price, but also to the designer's experience, human resources, deadline for design development, design solutions of the designer, etc. In the cases when contracting authorities focus on the lowest price criterion, the companies offering abnormally low prices are often awarded. Consequently, designs are delayed, and then their price rises, simplified technical solutions are being approved.

When purchasing design services, it is necessary to be very precise when establishing the qualification requirements for the service suppliers. Professional experience and technical capacity requirements should depend on the complexity and scope of the object of procurement, and the specific information about the previously executed design contracts of similar nature and complexity is to be defined better to include design description and scope, value, legal status, contractual and actual deadline for the rendering of design services. This would enable the wider participation of the tenderers with professional and technical capacity to provide sufficient quality of the services procured.

Also, in order to improve the quality of design, is necessary to set up the provisions regulating the responsibility of the parties to the contract. The service provider should be liable to liquidate damages of the direct losses of the employer caused by improper structure design and for the financial damage suffered. The designer, failing to eliminate a deficiency or defect within a reasonable period of time agreed by the parties should be obliged to pay liquidated damages to the employer (e.g. 10 per cent of the total design contract price) and reimburse the expenses incurred when eliminating defects or doing additional design works [7].

Terms of reference for technical design. An employer, when drawing up terms of reference for the structure technical design is to examine in detail, clearly and comprehensively, the needs, goals, purpose of the structure, as well as to examine in detail the current situation. Also, depending on whether the design is developed for a new building or reconstruction of the existing one, the employer is to describe, clearly and unambiguously, the systems to be reconstructed or installed anew. Also the employer, which has little experience with the development of terms of reference for the development of technical design objectively defining the design scope based on the funds available to the employer for construction, should employ a consultant for the development of terms of reference. The more detailed and comprehensive is the terms of reference, the 
better is the evaluation by a designer of all circumstances and its ability to develop qualitative technical design for optimum price, acceptable to the employer.

Construction cost estimates and arrangement of construction works. Designers use recommended average works, machinery and material costs published by UAB Sistela when developing the cost estimates of technical designs for structure reconstruction or new construction. Preparation of the building reconstruction or new construction projects in the technical designers However, although UAB Sistela operates since 1992, but until now it does not have average works, machinery and material costs for railway-specific works [8]. For this reason, designers preparing technical railway reconstruction or new construction designs use the unit prices of the works of comparable/similar nature, which include the use of different machinery than the one used in railways (e.g., diesel locomotives, wagons, track layers, track alignment machines, etc.), totally ignoring the fact that railway projects are to be implemented during track possessions (e.g., when track possessions last $6,8,12,24$ or more hours depending on the complexity of the work). In order to carry out the works during track possessions, the machinery could not be left on site, so machines are to be brought to the site only when a track possession starts, and they are to leave the tracks and free the way prior to the expiry of a track possession to enable the renewal of train traffic. In the event of the failure of a contractor to renew train traffic after track possession, a fine for every minute of delay is to be applied and delay damages are to be paid for the unplanned train delay. Therefore, the designer, when preparing construction arrangement part of the technical design, is to examine the machinery, used in railway track construction or reconstruction, available in the respective market, their capacity, the technology works and, in close collaboration with the employer or railway infrastructure manager, to determine the frequency and length of track possessions to be able to develop a detailed project implementation timetable and thus properly estimate project implementation time and project costs. The experience shows that improperly planned project schedule or the estimated project cost may differ from those offered by tenderers by several tens of percent, and the actual duration of the project implementation may take much longer than planned by the employer. Because of what an employer may suffer direct and indirect losses.

\section{Recommendations}

Aiming at the quality improvements of the technical design it would advantageous, when selecting the designer through public tendering procedure, to choose the criteria of economic advantage rather than that of the lowest price. Furthermore, the design contract should contain provisions envisaging the liquidated damages for the direct losses suffered by the employer due to the improper structure design and for the financial damage suffered. In addition to all above, the terms of reference for technical design should be detailed and exhaustive so that the designer could take into consideration all peculiarities and develop qualitative technical design of a structure for an optimum price, acceptable to the employer. In order to obtain accuracy of price estimates in a technical design, is necessary to develop recommended railway-specific reconstruction or new construction unit prices, which also considered the performance of works during track possessions. Furthermore, it should be aimed that a designer, when estimating project implementation duration, had analyzed in detail and took into consideration the current supply and capacity of the railway machinery, available in a market, and, cooperating with an employer or railway infrastructure manager, evaluated the frequency and length of track possessions. The implementation of all the measures and cases discussed in this article would lead to the significant improvement of the design quality and the avoidance of the employer of the direct/indirect costs/losses resulting from additional design works and/or extended completion deadline.

\section{References}

[1] Rimkevičius, D. 2008. Basics of Construction. Handbook, 6-8.

[2] Law on Construction of the Republic of Lithuania, new edition valid from 1 July 2002, internet version at http://www.lacc.lt/dokumentai/teises-aktai

[3] Technical Construction Regulation STR 1.05.06:2010 Structure Design, current internet version at: http://www.am.lt/VI/index.php\#a/12476

[4] Model terms of reference for the development of technical design, internet version at http://www.lacc.lt/lt/dokumentai/pasiulymai

[5] Technical Construction Regulation STR 1.01.05:2007 Regulatory Technical Documents of Construction, current internet version at: http://www.am.lt/VI/index.php\#a/12476

[6] Markevičienė, E. 2012. The Verslo Žinios newspaper, internet version at http://vz.lt/article/2012/4/11/viesieji-pirkimai-maza-kaina-zema-kokybe-betvisiems-ramu\#ixzz2ruSrZgyA ;

[7] Website Economics at http://www.ekonomika.lt/naujiena/keliams-projektuoti-aiskesnes-viesuju-pirkimu-salygos-19504.html\#ixzz2ruTP34aC;

[8] UAB SISTELA website. Internet version at http://www.sistela.lt/ 